\title{
Myringoplasty with Autologous Fat
}

\author{
Felix Salas* \\ Caracas Venezuela Military Hospital, USA
}

Submission: June 30, 2016; Published: October 12, 2016

*Corresponding author: Felix Salas, Caracas Venezuela Military Hospital, Institute of San Bernardino, ENT AV. Cons Cajigal, San Bernardino, Caracas Venezuela, code no.3 1071, South America, Tel: +586145990; Email: fasbjr@hotmail.com

\begin{abstract}
Objective: Since the first myringoplasties late nineteenth century were made, they have used a variety of fabrics and materials for closure of perforations as perichondrium, periosteum, dura mater, fascia, veins, cartilage and autologous fat. The literature agrees that all sources of available grafts are preferred those that are readily available in the operating field and do not modify the properties of the eardrum vibroelásticas and therefore the patient's hearing. Myringoplasties traditionally practiced in the operating room under general anesthesia in most hospitals, however, such procedures can be performed relatively frequently under local anesthesia in the area of consultation.

Purpose: The purpose of this paper is to present the casuistry of simple tympanic perforation closure under local anesthesia in the office during my training as a resident of the specialty. 6 adult patients admitted with no more single tympanic perforation 10\%, with no evidence of cholesteatoma, chronic otitis media or acute otitis media at the time of the procedure. Under microscopic view desepitelizar proceeded to approximately $2 \mathrm{~mm}$ margin around the piercing and autologous fat earlobe for closure was placed.
\end{abstract}

Results: 4 patients were female and 2 male, mean age 34.1 years, close drilling in the 6 patients without complications, average operating time of 30 min, 3 months and tracking correction conductive hearing loss.

Keywords: Myringoplasty; Autologous Fat; Local Anesthesia

\section{Introduction}

Myringoplasty is a term used to designate those surgical procedures that are intended to repair the tympanic membrane. Attempts to repair the tympanic membrane date back more than a century. In 1878 Berthold successfully closed a perforation with full-thickness skin and introduced the term 'myringoplasty' [1]. The parents of the current myringoplasty have been however, Zöllner and Wülstein in the early years 50 [2]. Since been described countless variants techniques differ as to the approach: endaural, BTE and transcanal well as graft placement with respect to Inlay (tranperforación) Overlay drilling (over drilling also known as lateral) and Underlay (under drilling or medial); always looking to improve results from both anatomically as functional [3].

Since the first myringoplasties late nineteenth century were made, have been introduced different tissues as grafts:
a. perichondrium (Goodhill),
b. Fascia ( storis),
c. Cornea (Forman),
d. periosteum (Chiossone),
e. pericardium (Trombetta),
f. Homologous Vena (Nickel).

Wehrs fat used earlobe as graft dehiscence skin of the ear canal. Brandow also used fat earlobe to repair small perforations of the tympanic membrane. In 1964, Sterkers [2] reported using abdominal fat miringoplastia [2] currently compressed to autologous grafts are preferred because a higher rate of longterm success is achieved and the rejection of the implanted material body is avoided; literature agrees that all sources of available grafts are preferred those that are readily available in the operating field and do not modify the properties of the eardrum vibroelásticas and therefore the patient's hearing [4].

The advantages of the use of autologous fat in patients with small tympanic membrane can be summarized in several points:

a) It is easy to obtain and is in the same operative field,

b) Taking into account cell migration centripetal membrane tympanic, you can place an autologous viable tissue and vascularized fat, which serve as a bridge support for cell migration in the process of closure of the perforation,

c) Costs for the patient are reduced and health institutions,

d) Use of surgical instruments is minimized and the time spent in the procedure

e) Useful as a minimally invasive procedure for patients 


\section{Global Journal of Otolaryngology}

who are not unable or unwilling to undergo such procedures under general anesthesia [2].

\section{Materials and Methods}

A preliminary review of a prospective, longitudinal study of case studies of patients with simple tympanic perforation subjected to close at the office, under infiltrating local anesthesia with lidocaine, under microscopic view with Transcanal and technical approach Inlay with autologous fat lobe is presented the ipsilateral ear, in the period January 2009 - July 2009. Laboratory tests were performed: complete Hematology, Coagulation times, tonal and vocal audiometry was performed using as an indicator of effectiveness the closure of the perforation and decreased percentage of hearing loss greater than or equal to $10 \%$, by calculating the average conversational frequencies ( $\Sigma$ average thresholds $500-1000-2000-3000 \mathrm{~Hz} / 4$ ) and Percentage of mono loss (x Frequency Conversational - 25 $x$ 1.5). The monitoring protocol was performed in patients with otomicroscopy successive controls and Otovideoendoscopia 7 days 15, 30, 60 and 90 after the completion of the procedure; and with control audiometric at 3 months. The results are presented using descriptive statistics: tables and graphs with absolute values and measures of central tendency.

\section{Inclusion criteria}

i. Patients over 18 years.

ii. Patients suffering from simple tympanic membrane (no evidence of acute or chronic cholesteatoma or when practicing the procedure otitis media).
iii. Size no more than $10 \%$.
iv. Drilling Central type.
v. No history of chronic middle ear disease.
vi. Informed consent.

\section{Exclusion criteria}

a. Acute at the time of the disease process.

b. Alteration of haematological parameters.

\section{Instrumental}

The basic surgical instruments for myringoplasty were used. Rosen needles, tweezers type MicroHartmann, Suctions diameters 3, 5 and $7 \mathrm{fr}$, ear specula set from 4.5 -7 Karl Storz otologic microscope. Minor Surgery Equipment for obtaining graft.

\section{Surgical technique}

i. Asepsis and antisepsis of the operative area with Gerdex $\AA$ and placement of sterile fields.

ii. Infiltration of anesthetic / vasoconstrictor solution, Adrenalin 1: 100,000 units in Cifarcaína 1\%.

iii. Incision back of the ipsilateral ear lobe punctures with hojilla 15.

iv. Divulsion to visualize subcutaneous fat. Gripping and cutting it with sufficient size for making graft. Placing the same sheet of glass on a drop of saline.

v. Wound closure with Nylon 4/0.

vi. Under otomicroscópica vision aural speculum placement. Infiltration of the four walls of the duct, viewing drilling (Figure 1).

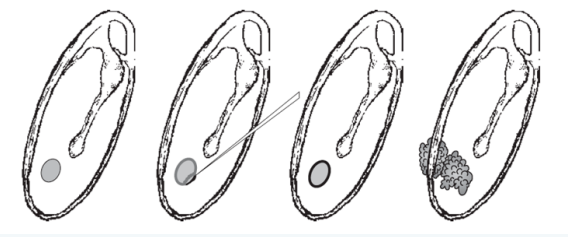

Figure 1: A) Tympanic drilling representing 10\% approx.

B) Epithelialization edges $203 \mathrm{~mm}$.

C) Representation of the bloody edges.

D) Fat Graft Placement plug-shaped or dumbbell.

vii. Puncture edge of the perforation and revival of removal sclerotic surface edges, edges epithelialization of 2-3 mm (Figures 2 \& 3).

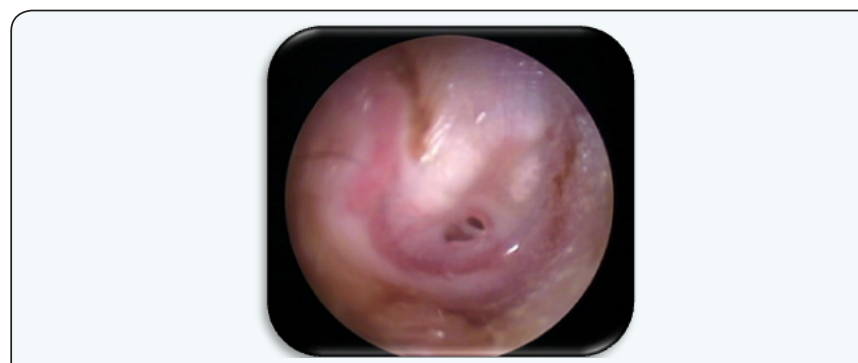

Figure 2: Appearance of a central tympanic perforation approximately $10 \%$.

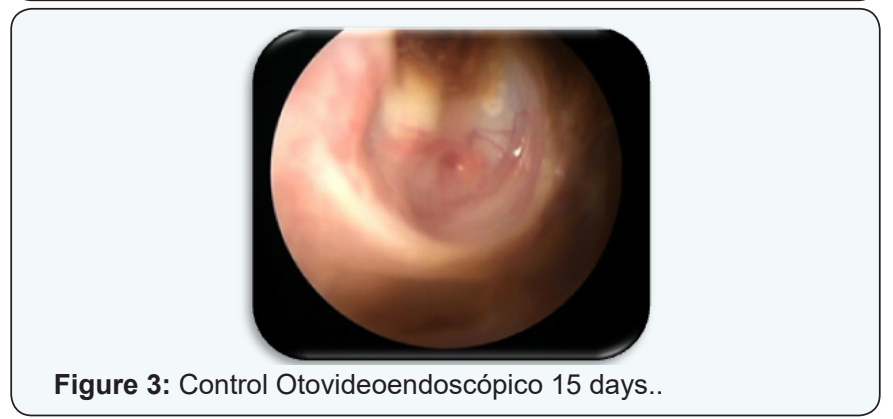

Figure 3: Control Otovideoendoscópico 15 days

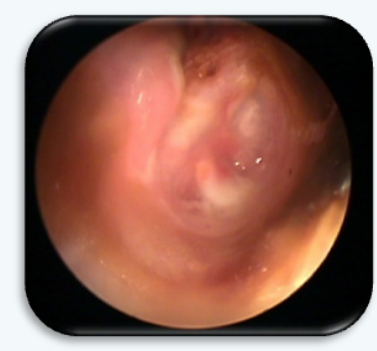

Figure 4: Control Otovideoendoscópico 60 days. 
viii. Placing the grafting technique Inlay (Transperforación) Verification graft placement on both sides of the tympanic membrane (Figure 4).

ix. Placing occluder cotton ear canal.

\section{Results}

Table 1: Distribution of patients by sex.

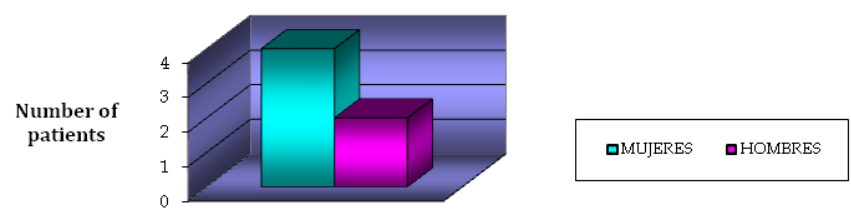

Table 2: Success (closing the drilling) vs. Flop (re-drilling).

\begin{tabular}{|c|c|}
\hline $\mathrm{x}$ Fcias Conversational & $33 \mathrm{~dB}$ \\
\hline$\%$ Loss & $12 \%$ \\
\hline
\end{tabular}

Table 3: Preoperative.

\begin{tabular}{|c|c|}
\hline $\mathrm{x}$ Fcias Conversational & $33 \mathrm{~dB}$ \\
\hline$\%$ Loss & $12 \%$ \\
\hline
\end{tabular}

Table 4: Postoperative.

\begin{tabular}{|c|c|}
\hline$x$ Fcias Conversational & $26 \mathrm{~dB}$ \\
\hline$\%$ Loss & $2 \%$ \\
\hline
\end{tabular}

A total of 6 patients with diagnosis of perforated eardrum Simple were operated by Transcanal approach with Inlay Technique with Autologous fat ipsilateral ear lobe, of which 66.6 $\%$ were women and $33.4 \%$ men. The mean age was 34.1 years, with a minimum age of 20 years and a maximum age of 55 years (Table 1). Regarding the results anatomo functional closure of the perforation was achieved in $100 \%$ of cases operated without complications from the procedure, average operating time of 30 min, with maximum follow-up of 3 months (Table 2). Finally, the hearing gain, considered a decrease in the percentage of mono loss by 10 or more percentage points, a decrease of $10 \%$ was obtained (Tables 3 \& 4).

\section{Discussion}

Fat earlobe as a graft to repair defects of the tympanic membrane is used for more than 35 years fat earlobe is selected for its higher content of connective tissue, fat compared to other sites, and their best chance of integration revascularization, plus it is in the same surgical field. Myringoplasty with fat grafting is a good choice, simple and quick to close tympanic membrane whose area is not more than $25 \%$ of the total area of the tympanic membrane $[5,6]$, option that variable results are achieved that exceed $90 \%$ in series like RB Mitchell and collaborators in a total of 342 adult patients 6 and another report by the same authors in 18 children [7]; also results of $82.4 \%$ success in a series of 45 patients (Ozgursoy, OB. and Yorulmaz I) with small perforations and case reperforaciones 5 . The variability of successful results of different series lies in the age as a determining factor as the pediatric population suffers otological pathology more frequently due to ventilation poor tympanic cavity immaturity and dysfunction eustachian tube and its own range 5 recurrent respiratory infections.

The fact that selected patients with tympanic perforations no larger than $10 \%$, is the success rate of $100 \%$ achieved in this study; in relation to the exclusion of patients with chronic or acute pathology, there is controversy in the literature as to the results obtained in the presence or not of secretion as a limiting factor in the integration process of injerto [8]. At an appropriate re-epithelialization and complete closure of the perforation achieved meant a functional result given by the $10 \%$ decrease in the differential between the percentages of hearing loss monaural gain.

\section{Conclusion}

Myringoplasty autologous fat graft is a useful tool in the closure of small tympanic membrane. The success rate varies considerably while smaller the drilling, as well as in the absence of acute or chronic middle ear mucosa disease very quick and easily performed under local anesthesia in the area of consultation, which warrants minimal surgical equipment and instrumentation, with which the number of hospital patients awaiting surgical decongests shift and allows favorable results anatomofunctional procedure.

\section{References}

1. Machin Gonzalez Victoriano, Vieito Espineira Rodolfo, Benito Soler Isabel, Freyre Serentil, Juan Carlos (1997) Miringoplastias. Results Anatomofunctional. Rev Cubana Cir 36(1): 6-12.

2. Leticia Guzmán Martínez, Alejandro Fuentes Cienfuegos (2005) Myringoplasty with Fat Grafting. Annals Doctors Hospital ABC 50(2): 62-65.

3. Bordure, Phillipe (2007) Otological and otoneurological Surgery Elsevier -Masson Capítulo 6: 77-83.

4. Rivas, Jose A (2000) Treaty of Otology and Audiology. Diagnosis and surgical treatment Editorial Amolca. Capítulo 15: 320-26.

5. Kato M, Jackler RK (2006) Simple tympanic perforation closure techniques evaluation. Otolaryngol Head Neck Surg 115(6): 538-547.

6. Mitchell RB, Pereira KD, Lazar RH (1997) Fat graft myringoplasty children a safe and successful day-stay procedure. J LaryngolOtol 111(2): 106-108.

7. Mitchell RB, Pereira KD, Younist RT, Lazar RT (1996) Bilateral fat graft myringoplasty in children. Ear Nose Throat J 75(10): 652-656.

8. Aponte Romo, Horacio (2007) Factors influencing the hearing gain of patients with chronic otitis media after myringoplasty. An Orl Mex 52(1): 22-28. 
Your next submission with JuniperPublishers will reach you the below assets

- Quality Editorial service

- Swift Peer Review

- Reprints availability

- E-prints Service

- Manuscript Podcast for convenient understanding

- Global attainment for your research

- Manuscript accessibility in different formats

( Pdf, E-pub, Full Text, Audio)

- Unceasing customer service

- Track the below URL for one-step submission

http://juniperpublishers.com/online-submission.php 